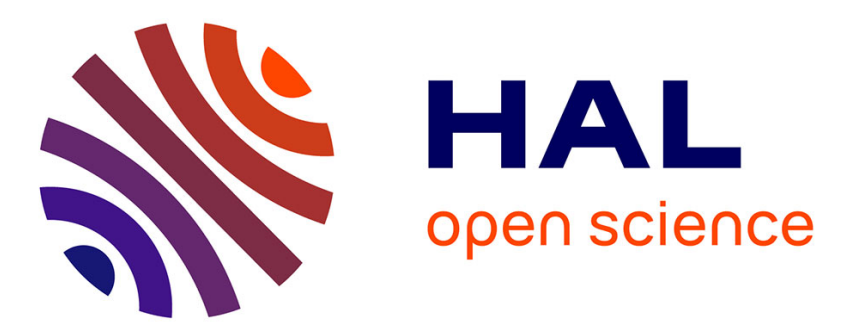

\title{
Changes in the acid gelation of skim milk as affected by heat-treatment and alkaline $\mathrm{pH}$ conditions
}

Fanny Guyomarc'H, Orlane Mahieux, Marie Renan, Marc Chatriot, Valérie Gamerre, Marie-Hélène Famelart

\section{- To cite this version:}

Fanny Guyomarc'H, Orlane Mahieux, Marie Renan, Marc Chatriot, Valérie Gamerre, et al.. Changes in the acid gelation of skim milk as affected by heat-treatment and alkaline $\mathrm{pH}$ conditions. Le Lait, 2007, 87 (2), pp.119-137. hal-00895639

\section{HAL Id: hal-00895639 \\ https://hal.science/hal-00895639}

Submitted on 1 Jan 2007

HAL is a multi-disciplinary open access archive for the deposit and dissemination of scientific research documents, whether they are published or not. The documents may come from teaching and research institutions in France or abroad, or from public or private research centers.
L'archive ouverte pluridisciplinaire HAL, est destinée au dépôt et à la diffusion de documents scientifiques de niveau recherche, publiés ou non, émanant des établissements d'enseignement et de recherche français ou étrangers, des laboratoires publics ou privés. 


\title{
Changes in the acid gelation of skim milk as affected by heat-treatment and alkaline $\mathbf{p H}$ conditions
}

\author{
Fanny GUYOMARC'H ${ }^{a *}$, Orlane MAHIEUX ${ }^{a}$, Marie RENAN ${ }^{b}$, \\ Marc CHATRIOT ${ }^{b}$, Valérie GAMERRE ${ }^{b}$, Marie-Hélène FAMELART ${ }^{\mathrm{a}}$ \\ a Inra-Agrocampus Rennes, UMR1253, Science et Technologie du Lait et de l'CEuf, 65 rue de St Brieuc, \\ 35042 Rennes cedex, France \\ b EPI Ingrédients, ZI de l'Hermitage, BP 108, 44153 Ancenis cedex, France
}

Received 8 December 2006 - Accepted 26 January 2007

\begin{abstract}
In an attempt to improve the acid gelation properties of heated milk, or to reduce the heat load necessary to obtain significant acid gelation properties, skim milk adjusted at $\mathrm{pH}$ values ranging from 6.7 to 10.5 was heat-treated for $10 \mathrm{~min}$ at temperatures ranging from 25 to $95{ }^{\circ} \mathrm{C}$ then neutralised to $\mathrm{pH}$ 6.7. Protein composition of the serum and micellar phases of milk and separation of the protein particles present in the serum phase of milk indicated that formation of micelle-bound heat-induced whey protein/ $/$-casein aggregates was prevented from $\mathrm{pH} 7.5$ upward, to the benefit of serum aggregates. Aggregates were formed in milk at $\mathrm{pH} 9.5$ and 10.5 even at mild heating temperature $\left(65-75^{\circ} \mathrm{C}\right)$, while temperatures of 85 or $95^{\circ} \mathrm{C}$ were necessary at lower $\mathrm{pH}$ values. Size of the aggregates decreased as $\mathrm{pH}$ of heat-treatment increased. Quality of the results was however reduced because of the extensive dissociation of caseins on alkaline treatment and of side mechanisms like Maillard reaction at high $\mathrm{pH}$ and temperature. However, some relationships could be found between the occurrence of aggregated whey protein and $\kappa$-casein and higher elastic modulus of the acid gels after heating at low temperature/high $\mathrm{pH}$ or high temperature/low alkaline $\mathrm{pH}$ values of skim milk.
\end{abstract}

whey protein / $\kappa$-casein / heat-treatment / pH / acid gel

摘要 - 热处理和碱性条件下对脱脂乳酸凝固作用的影响。调整脱脂乳的 $\mathrm{pH} 6.7 \sim 10.5$, 在 $25 \sim 95^{\circ} \mathrm{C}$ 鸆加热 $10 \mathrm{~min}$, 然后再中和到 $\mathrm{pH}$ 6.7, 研究上述条件下加热牛奶酸凝固性的提高以 及在减少热负荷的情况下牛奶的凝固特性。根据对牛乳清液相和酪蛋白微团相蛋白质组成 的分析和牛乳清液相中蛋白质颗粒的分离, 表明当 $\mathrm{pH}>7.5$ 时, 在酪蛋白微团相中热致的 乳清蛋白 / $\kappa$ - 酪蛋白聚合物的形成被抑制, 但在清液相中则有利于乳清蛋白 $/ \kappa$ - 酪蛋白聚合 物的形成。当牛乳在 $\mathrm{pH} 9.5$ 和 10.5 时, 甚至在中温条件 $\left(65-75^{\circ} \mathrm{C}\right)$ 下, 在乳中可以形成乳 蛋白聚合物, 而在 85 或 $95^{\circ} \mathrm{C}$ 鸕时, 形成凝聚物 $\mathrm{pH}$ 值要较低一些, 并且形成凝聚物的颗 粒随着热处理条件下 $\mathrm{pH}$ 的增加而减少。由于在碱性条件下酪蛋白微团的解离以及在高 $\mathrm{pH}$ 、 高温年美拉德反应的发生, 导致了最终产品品质降低。本研究探讨了脱脂乳在低温高 pH 或 高温低 $\mathrm{pH}$ 条件下, 乳清蛋白/ $\mathrm{\kappa}$-酪蛋白聚合物的形成和获得较高酸凝胶塑性模型之间的关系。

乳清蛋白 / $\kappa$ - 酪蛋白 / 热处理 / pH / 酸凝胶

\footnotetext{
* Corresponding author (通讯作者): fanny.guyomarch@ rennes.inra.f r
} 
Résumé - Modification de l'aptitude à la gélification acide du lait écrémé suite à un traitement thermique à pH alcalin. Dans l'objectif d'améliorer l'aptitude à la gélification acide du lait traité thermiquement ou de réduire la charge thermique nécessaire à l'obtention d'une aptitude significative, du lait écrémé a été ajusté à des $\mathrm{pH}$ variant de 6,7 à 10,5, traité thermiquement pendant 10 min à des températures variant de 25 à $95^{\circ} \mathrm{C}$ puis neutralisé. La composition en protéines des phases sérique et micellaire du lait et la séparation des particules présentes dans le sérum indiquaient que la formation d'agrégats thermo-induits de protéines sériques et de caséine $\kappa$ dans la fraction micellaire est inhibée à $\mathrm{pH} \geq 7,5$ au profit des agrégats sériques. Des agrégats étaient formés à $\mathrm{pH} 9,5 \mathrm{et}$ 10,5 dès $65^{\circ} \mathrm{C}$, tandis que des températures de 85 ou $95^{\circ} \mathrm{C}$ étaient nécessaires à $\mathrm{pH}$ moins élevé. La taille des agrégats était inversement proportionnelle au $\mathrm{pH}$ de traitement thermique. La qualité des résultats était cependant médiocre du fait de la dissociation importante des caséines à $\mathrm{pH}$ alcalin et de la dégradation des protéines à pH et températures élevés (e.g. réaction de Maillard). Cependant, une relation entre la présence d'agrégats et les qualités rhéologiques des gels acides formés a pu être identifiée à basse température/pH élevé et à haute température/pH modéré.

protéine sérique / caséine $\kappa$ / traitement thermique / $\mathrm{pH} /$ gélification acide

\section{INTRODUCTION}

High heat-treatment of milk $\left(85-95{ }^{\circ} \mathrm{C}\right.$ for several minutes) is classically applied in the manufacture of yoghurt and other fermented milk, where the acid gel is expected to form early, to develop a firm texture and to show high whey retention capacity. This ability of the heated milk to form acid gels with good textural properties has been attributed to denaturation of the whey proteins and to their interaction with $\kappa$-casein through thiol-disulfide exchange and hydrophobic interaction to yield new particles, the whey protein/ $\kappa$-casein aggregates, that are located both on the surface of the casein micelles (micelle-bound aggregates) and in the serum phase of milk (serum aggregates) $[2-4,9,19,43,45,46]$. While whey proteins alone are able to form heatinduced complexes [12,32], in milk various results have demonstrated the involvement of $\kappa$-casein in a large part, if not all, the aggregates formed $[13,19,31]$ albeit the formation of $\kappa$-casein-free aggregates can not yet be excluded [46]. Recent studies have suggested that the serum aggregates provided the milk with improved acid gelation properties compared to those obtained with the micelle-bound aggregates [5, 6, 20, 40]. The proposed explanations for these effects were that the serum aggregates had a higher $\mathrm{pH}$ of gelation than that of the casein micelle (with or without attached denatured whey proteins), that stability of the casein micelles was reduced as a result of the involvement of $\kappa$-casein in the serum ag- gregates and that gelation was enhanced by the increased number of acid-precipitable particles and/or by the triggering effect of the formation of an intermediate gel when serum aggregates were present. It has also been shown that distribution of the heatinduced whey protein/K-casein aggregates between the serum and the colloidal phases of milk depended on the $\mathrm{pH}$ of heat-treatment; namely, that formation of predominantly serum aggregates was favoured at alkaline $\mathrm{pH}$ values of heating [5, 6, 29, 40, 45]. All these studies used moderate alkaline $\mathrm{pH}$ values $(\mathrm{pH} \leq 8.1)$; however, Monahan et al. [32] have shown that disulfide polymers of whey proteins could be formed in solutions of whey protein isolate (WPI) at $\mathrm{pH} 9$ or 11 during mild or even in absence of heat-treatment, up to the formation of gels at sufficiently high $\mathrm{pH}$ or ionic strength $[30,32]$. This method has been applied by Connolly [8] to aggregate and isolate proteins in mixtures of milk, whey and/ or soy milk at temperatures below $70{ }^{\circ} \mathrm{C}$. Combination of heat treatment and alkaline $\mathrm{pH}$ has also been applied to the manufacture of milk protein isolates (MPI), resulting in increased protein yield, increased rehydration properties and higher viscosity of the reconstituted powder in particular cases [7, 16, 17]. Grufferty and Mulvihill [16] have for instance obtained MPI from milk heated at $\mathrm{pH} 10$ and $60{ }^{\circ} \mathrm{C}$ for $3 \mathrm{~min}$ whose protein yield competed with those obtained at neutral or mildly alkaline $\mathrm{pH}$ on heating at 90 $95{ }^{\circ} \mathrm{C}$ for $15 \mathrm{~min}$, and showed that these 
results depended on the formation of disulfide aggregates of $\kappa$-casein and whey proteins. Conversely, Leaver and Law [23] have submitted skim milk at pH 10 to 12 for $2 \mathrm{~h}$ in order to bind the whey protein to caseins and yield co-precipitates; however, their analysis of the resulting sample by trypsine digestion and mass spectrometry did not evidence any significant formation of intermolecular disulfide bridges.

In some of these studies, recovery of the protein fraction was performed using acidification to $\mathrm{pH} 4.6[16,17]$. The disulfide aggregates obtained in strong alkaline and mild heat-treatment conditions therefore seemed acid-precipitable, and consequently, seemed good candidates for the formation of acid yoghurt-type gels. The objective of this study was therefore to evaluate the interest of high $\mathrm{pH}$ conditions on heat-treatment of skim milk, either as a means to increase gel strength or as a means to reduce the heat load necessary to yield gel properties comparable to the reference gel texture obtained on acidifying milk pre-heated at $\mathrm{pH} 6.7$ and at $95^{\circ} \mathrm{C}$ for $10 \mathrm{~min}$.

\section{MATERIALS AND METHODS}

\subsection{Reconstituted skim milk}

Milk was reconstituted as $100 \mathrm{~g} \cdot \mathrm{L}^{-1}$ ultra-low heat skim milk powder (Whey Protein Nitrogen Index $=9.5$ [41]) and $0.2 \mathrm{~g} \cdot \mathrm{L}^{-1}$ sodium azide in stirred deionised water at $40{ }^{\circ} \mathrm{C}$. The milk was stirred for at least one hour following complete dissolution, then left overnight at $5{ }^{\circ} \mathrm{C}$ to complete the process.

\subsection{Milk ultrafiltration permeate}

Milk ultrafiltrate (MUF) was prepared from fresh pasteurised milk on a $8-\mathrm{kg} \cdot \mathrm{mol}^{-1}$ molecular weight cut-off TAMI membrane (Tami Industries, Nyons, France) and stored at $5{ }^{\circ} \mathrm{C}$ after addition of $0.5 \mathrm{~g} \cdot \mathrm{L}^{-1}$ sodium azide. $\mathrm{pH}$ of the MUF was 6.7.

\subsection{Other materials}

Other chemicals were from Sigma (St-Quentin-Fallavier, France), Panreac
(Barcelone, Spain), Merck (Fontenaysous-Bois, France), Prolabo (Fontenaysous-Bois, France) or Carlo Erba (Val-deReuil, France) and were of analytical grade. Solvents were obtained from Carlo Erba and were of HPLC grade.

\section{4. pH adjustement}

Adjustment of the $\mathrm{pH}$ of heat-treatment was performed at least $\sim 2 \mathrm{~h}$ prior to heating. Two hundred-mL samples of reconstituted skim milk were first equilibrated at $25^{\circ} \mathrm{C}$ in a thermostated water-bath for $30 \mathrm{~min}$, then $\mathrm{pH}$ was adjusted at $\mathrm{pH} 7.5,8.5,9.5$ and 10.5 using $\mathrm{NaOH} 5 \mathrm{~mol} \cdot \mathrm{L}^{-1}$. The samples were left with agitation for $2 \mathrm{~h}$ at room temperature, and during that time the $\mathrm{pH}$ was measured every $\sim 30$ min to ensure equilibration between measurements and further adjusted if necessary. Much care was taken so that the volume of $\mathrm{NaOH}$ added to the milk samples was minimum $\left(\leq 8 \mathrm{~mL} \cdot \mathrm{L}^{-1}\right)$ to avoid significant dilution. Adjusted $\mathrm{pH}$ values were all within $\pm 0.05 \mathrm{pH}$ units.

\subsection{Heat-treatment}

After alkalinisation, the 200-mL samples of milk were placed in 250-mL Schott bottles and heat-treated at $25,65,75,85$ or $95^{\circ} \mathrm{C}$ for $10 \mathrm{~min}$ in a thermostated waterbath. The bottles were continuously handshaked throughout heat-treatment and cooling. The heating-up period was $\sim 9 \mathrm{~min}$ at $65^{\circ} \mathrm{C}, \sim 9.5 \mathrm{~min}$ at 75 and $85^{\circ} \mathrm{C}, \sim 13 \mathrm{~min}$ at $95{ }^{\circ} \mathrm{C}$ and the milks were maintained at the targeted temperature for another $10 \mathrm{~min}$. The milks were then cooled down to room temperature in agitated ice water, and the time to reach $\sim 25^{\circ} \mathrm{C}$ was $\sim 3 \mathrm{~min}$. The milk samples were then equilibrated at $25^{\circ} \mathrm{C}$ in a thermostated water-bath for $1 \mathrm{~h}$. At this stage, a $30-\mathrm{mL}$ sample of each milk was taken and ultracentrifuged (Sect. 2.8) prior to analysis of the supernatant (or serum phase) by size exclusion chromatography (SE-FPLC) as described in Section 2.9.

\subsection{Neutralisation}

The 200-mL samples of alkalinised, heat-treated skim milk equilibrated at $25^{\circ} \mathrm{C}$ 
were brought to $\mathrm{pH} 6.7$ by addition of $5 \mathrm{~mol} \cdot \mathrm{L}^{-1} \mathrm{HCl}$ under stirring and further correction every $\sim 30$ min until the $\mathrm{pH}$ was stable. The volume of $\mathrm{HCl}$ added to the milk samples was $\leq 6 \mathrm{~mL} \cdot \mathrm{L}^{-1}$. At this stage, another 30-mL sample of each milk was taken and ultracentrifuged prior to analysis of the supernatant (or serum phase), the resuspended pellet (or micellar phase) and of the starting milk by reverse-phase high performance liquid chromatography (RPHPLC) as described in Sections 2.8., 2.10 and 2.11. The milks were then stored at $4{ }^{\circ} \mathrm{C}$ until analysis.

\subsection{Dynamic light scattering}

Particle sizes in the alkalinised, heattreated samples was measured prior to and after neutralisation to $\mathrm{pH} 6.7$ within $2 \mathrm{~d}$ after heat-treatment using dynamic light scattering (DLS) at a set angle of $90^{\circ}$ on a Zetasizer Malvern 3000 HS (Malvern Instruments, Orsay, France). The laser was a He-Ne laser, with $633 \mathrm{~nm}$ wavelength. The solution was brought to $25^{\circ} \mathrm{C}$ in a thermostated water-bath, diluted in the appropriate milk ultrafiltration permeate (MUF) to meet the Zetasizer operating range, and allowed to stand at $25^{\circ} \mathrm{C}$ for $20 \mathrm{~min}$ to ensure proper equilibrium of the diluted system prior to analysis. The solution was then transferred to 2-mL disposable cuvettes for measurement. The refractive index of the MUF was 1.3416 and the viscosity of the MUF was $0.99 \mathrm{mPa} \cdot \mathrm{s}$ at $25^{\circ} \mathrm{C}$. The results given are the average of 10 readings, and each sample was analysed 2 or 3 times. Data was visualised using a CONTIN model, and the mode(s) of the weight-averaged particle size distribution were considered.

Ultrafiltration permeates of skim milk samples adjusted at $\mathrm{pH} 7.5,8.5,9.5$ and 10.5 were obtained by ultracentrifugation of the milks to remove the casein micelles (see Sect. 2.8), and ultrafiltration at room temperature on a stirred cell system assembly (Pall Life Science, St Germain-en-Laye, France) equipped with a $10-\mathrm{kg} \cdot \mathrm{mol}^{-1}$ cutoff membrane.The $\mathrm{pH}$ values of the collected permeates were respectively $7.5,8.1$, 8.5 and 10 instead of $7.5,8.5,9.5$ and 10.5 and were adjusted to their target values using
$5 \mathrm{~mol} \cdot \mathrm{L}^{-1} \mathrm{NaOH}$. These adjusted $\mathrm{pH}$ values were stable for at least $8 \mathrm{~d}$. Low-shear viscosity measurement (Low-Shear 30 equipped with 11 and $12 \mathrm{~mm}$ coaxial cylinders, Contraves, Zurich, Switzerland) was performed at $25{ }^{\circ} \mathrm{C}$ to ensure that viscosity of the different MUF was unchanged with $\mathrm{pH}$.

\subsection{Separation of the serum and colloidal phases of skim milk}

Separation of the serum and colloidal phases of heat-treated and control milk samples was performed on $15-\mathrm{mL}$ aliquots of milk using ultracentrifugation on a Sorvall Discovery 90 SE centrifuge (Kendro Laboratory Products, Courtaboeuf, France) equipped with a 50.2 Ti rotor (Beckman Coulter, Fullerton, CA, USA). The samples were spun at $19400 \mathrm{rpm}(\sim 33000$ average $g)$ for $65 \mathrm{~min}$ at $20^{\circ} \mathrm{C}$. The supernatants were collected by simply pouring them into a container without draining or washing of the pellets. This fraction was designated as the "serum phase" or "serum". The total volume, as well as $12 \mathrm{~mL}$ of each serum, was weighted. From the data obtained with $12 \mathrm{~mL}$ of serum, the mass density of the serum was calculated, which allowed calculation of the total volume of the serums, Vs, to be used in calculation of the mass balance of targeted proteins (see Sect. 2.11). It was observed that the mass density of the serum phase showed a tendency to increase from $1.024 \pm 0.005$ to $1.033 \pm 0.01 \mathrm{~kg} \cdot \mathrm{L}^{-1}$ as $\mathrm{pH}$ increased from 6.7 to 10.5 , probably as a result of the dissociation of caseins (not shown). The pellets were resuspended in $12 \mathrm{~mL}$ of milk ultrafiltrate at room temperature for up to $48 \mathrm{~h}$ under constant agitation. This fraction was designated as the "colloidal" or "micellar phase" of the milk sample and indeed contains a large majority of the casein material of milk [19]. The pellets were resuspended in $\mathrm{pH} 6.7$ milk permeate, no matter the initial $\mathrm{pH}$ of the milk sample, because these fractions were only used for the analysis of their protein composition under dissociating and denaturing conditions by reverse phase high-performance liquid chromatography (RP-HPLC). 


\subsection{Analysis of the milk serums by Size Exclusion Fast Protein Liquid Chromatography (SE-FPLC)}

Size Exclusion FPLC analysis of the serum of heat-treated or control $\mathrm{pH}$-adjusted milks was performed within 3 days after heat-treatment on a Sephacryl S-500 Hi-Prep 16/90 column (Amersham Biosciences, Orsay, France). The samples were filtered through $1.2 \mu \mathrm{m}$ filters (Pall Life Science). The separation was performed at room temperature under isocratic conditions using $0.1 \mathrm{~mol} \cdot \mathrm{L}^{-1}$ Tris, $0.5 \mathrm{~mol} \cdot \mathrm{L}^{-1}$ $\mathrm{NaCl}$ and $10 \mathrm{mmol} \cdot \mathrm{L}^{-1} \mathrm{NaN}_{3}, \mathrm{pH} 7$, as the mobile phase. Loop size was $0.5 \mathrm{~mL}$, flowrate was $0.5 \mathrm{~mL} \cdot \mathrm{min}^{-1}$, and absorbance was monitored at $280 \mathrm{~nm}$. Eluate fractions corresponding to the SE-FPLC separation peaks were collected, dialysed against deionised water, concentrated by freezedrying, resuspended in a volume of deionised water 200 times smaller than that of the initial collected peak eluate and immediately analysed by RP-HPLC.

\subsection{Reverse-Phase High Performance Liquid Chromatography (RP-HPLC)}

The protein composition of the initial milk samples, of its serum and colloidal phases separated by ultracentrifugation, and of the peak fractions collected during the separation of the serum by SE-FPLC were determined by RP-HPLC. The samples were diluted 5 times with denaturing buffer $\left(7 \mathrm{~mol} \cdot \mathrm{L}^{-1}\right.$ urea, $20 \mathrm{mmol} \cdot \mathrm{L}^{-1}$ BisTris Propane, $\mathrm{pH} 7.5,+5 \mu \mathrm{L} \cdot \mathrm{mL}^{-1}$ of fresh $\beta$-mercaptoethanol) then incubated for at least $1 \mathrm{~h}$ at room temperature. The column was an Apex wide-pore C18 column of $25 \mathrm{~cm}$ length, $0.46 \mathrm{~cm}$ inner diameter and $7 \mu \mathrm{m}$ bead diameter (Jones Chromatography, Hengoed, UK). Buffer A was $0.106 \%$ $\mathrm{v} / \mathrm{v}$ trifluoroacetic acid (TFA) in Milli-Q water (Waters, Molsheim, France). Buffer B was $0.1 \% \mathrm{v} / \mathrm{v}$ TFA in $80 \% \mathrm{v} / \mathrm{v}$ acetonitrile in Milli-Q water. The analysis was performed at $46{ }^{\circ} \mathrm{C}$ with a gradient of Buffer B increasing in steps from 43 to $100 \% \mathrm{v} / \mathrm{v}$ in $23 \mathrm{~min}$. Loop size was $30 \mu \mathrm{L}$, flow-rate was $1 \mathrm{~mL} \cdot \mathrm{min}^{-1}$ and detection was at $214 \mathrm{~nm}$.

\subsection{Quantification of heat-induced protein transfers between the serum and the colloidal phases of milk}

The proportions of $\kappa$-casein and whey proteins in both the micellar and the serum phases of milk were calculated by dividing the peak area of the protein ( $\kappa$-casein or whey proteins) in each fraction (micellar or serum phase) by the average peak area of the same protein in the total reconstituted, unheated, pH 6.7 skim milk (6 samples). Because RP-HPLC analysis was directly performed on the serum (i.e., missing the volume of the pellet) and on the pellet resuspended in a consistent volume $(12 \mathrm{~mL})$ of milk ultrafiltrate slightly smaller than that of the serum actually removed, concentrations of the whey proteins and $\kappa$-casein were over-estimated and could not be directly balanced as fractions of the initial $15 \mathrm{~mL}$ of milk. After the volume of serum, Vs, was calculated (see Sect. 2.8), a correction factor of Vs/15 was therefore taken into account in the calculation of the proportions of $\kappa$-casein or whey proteins in the serum phase. Similarly, the volume of the resuspended pellet, $\mathrm{Vc}$, was calculated as $\mathrm{Vc}=$ $12+(15-\mathrm{Vs}) \mathrm{mL}$ and a correction factor of $\mathrm{Vc} / 15$ was applied to the RP-HPLC areas of the analysed proteins.

\subsection{Viscoelastic properties of acid milk gels}

Formation of the acid gels was monitored by measuring the elastic modulus $\left(\mathrm{G}^{\prime}\right)$ of the system under acidification at $38^{\circ} \mathrm{C}$ using an AR1000 rheometer (TA Instruments, St Quentin-en-Yvelines, France) equipped with a coaxial geometry (DIN with a lateral gap of $1.95 \mathrm{~mm}$ and a bottom gap of $4 \mathrm{~mm}$ ). After equilibration of a volume of $60 \mathrm{~mL}$ of milk at $38^{\circ} \mathrm{C}, 11 \mathrm{~g} \cdot \mathrm{L}^{-1}$ of glucono- $\delta$-lactone (GDL) was added to the milk under stirring. The milk was stirred for $1 \mathrm{~min}$ to allow dispersion of the GDL then poured into the cup of the rheometer. After installation of the geometry was completed, a thin Inlab $423 \mathrm{pH}$ probe (Mettler-Toledo, Viroflay, France) was put in place so that the $\mathrm{pH}$ could be measured 


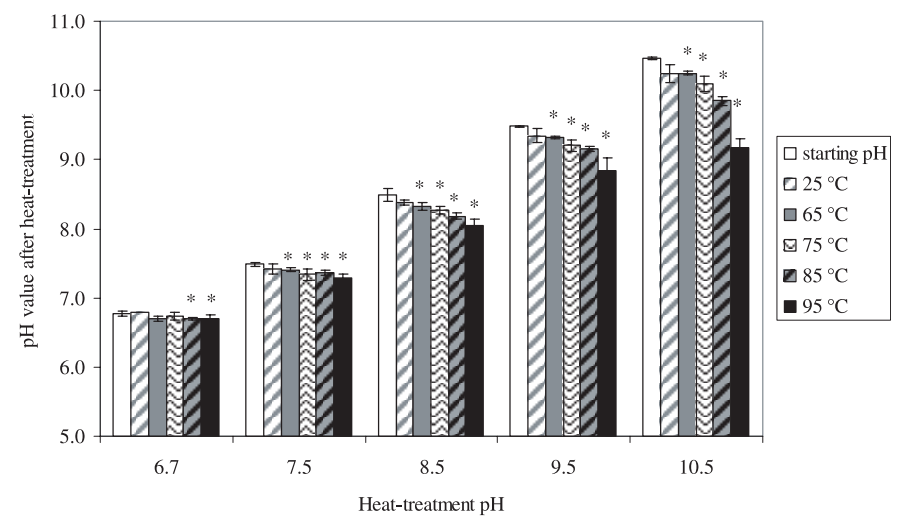

Figure 1. Average $\mathrm{pH}$ values of the milk samples adjusted at $\mathrm{pH} 6.7$ to 10.5 , prior to and after heattreatment for $10 \mathrm{~min}$ at the indicated temperatures. The star symbol $(*)$ indicates significant $\left(P_{0}<\right.$ $0.01) \mathrm{pH}$ change on heating.

directly in the rheometer and recorded (pHM220 Meterlab, Radiometer Analytical SAS, Villeurbanne, France). The milk sample was covered with a thin layer of mineral oil to prevent evaporation during analysis. The applied deformation was $0.1 \%$, frequency was $1 \mathrm{~Hz}$, and gel formation was followed for at least $8 \mathrm{~h} . \mathrm{pH} 4.9$ (latest gelation points, see Results) was reached within $3 \mathrm{~h}$.

\subsection{Colour measurement}

Colour measurement of the milk samples was performed after heat-treatment and neutralisation using chromametry (CR300, Konica Minolta, Carrières-sur-Seine, France). Analyses yielded the coordinates for the tested samples in the Hunter L*a*b* colour space; $\mathrm{L}^{*}$ is the luminance (increasing from dark/black to bright/white) and $\mathrm{a}^{*}$ and $b^{*}$ are the coordinates that define the dominant hue of the sample and its saturation (purity and intensity of the hue) on a circular $a^{*} ; b^{*}$ spectrum plane. Axis $\left(-a^{*}\right.$; $\left.+a^{*}\right)$ is from green to red and axis $\left(-b^{*}\right.$; $\left.+b^{*}\right)$ is from blue to yellow.

\subsection{Significance}

The presented results were obtained from 2 (at 65 and $85^{\circ} \mathrm{C}$ ) or 3 (at 25,75 and $95^{\circ} \mathrm{C}$ ) repetitions of complete sample prep- aration and analysis, except for SE-FPLC analysis where only 2 samples were obtained for each type of milk sample.

\section{RESULTS}

\section{1. pH and external aspect of the milks}

Figure 1 shows the average final values of the $\mathrm{pH}$ of the milk after heat-treatment at pH 6.7 to 10.5 and at 25 to $95^{\circ} \mathrm{C}$ for $10 \mathrm{~min}$.

The $\mathrm{pH}$ value of milk tended to decrease as a result of heat-treatment. This effect was increased as both the temperature and $\mathrm{pH}$ of heat-treatment were increased. It is well known that the heat-induced decrease of the $\mathrm{pH}$ of milk is essentially a consequence of the partial degradation of lactose due to the Maillard reaction, which is favoured in alkaline $\mathrm{pH}$ and high temperature conditions [47]. However, in the present study the $\mathrm{pH}$ differences that were applied between the $\mathrm{pH}$-adjusted milk samples were rather well maintained during heating.

Figure 2 shows pictures of the samples obtained after alkalinisation to $\mathrm{pH}$ 7.510.5 , heat-treatment at 25,75 and $95^{\circ} \mathrm{C}$ for $10 \mathrm{~min}$ prior to and following neutralisation to $\mathrm{pH}$ 6.7. The samples obtained at 65 and $85^{\circ} \mathrm{C}$ showed intermediate behaviour (not shown). 

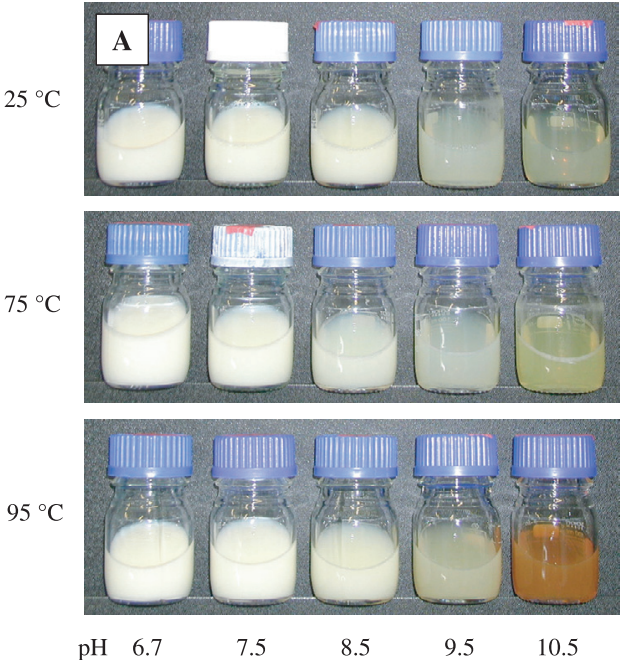

Figure 2. Pictures of typical skim milk samples as obtained after $\mathrm{pH}$ adjustment at $\mathrm{pH} 6.7$ to 10.5 (A, top row), heat-treatment at 25 to $95{ }^{\circ} \mathrm{C}$ for $10 \mathrm{~min}$ (A) and neutralisation to $\mathrm{pH} 6.7$ (B). The samples obtained at 65 and $85^{\circ} \mathrm{C}$ showed intermediate aspects and were omitted. The numbers indicate typical samples of the 3 different aspects of milk samples described in the text.

Very significant changes of the external aspect of the milk occurred during alkalinisation, heat-treatment and neutralisation. Increasing $\mathrm{pH}$ to 10.5 induced a reduction of the whiteness of the milks, most likely as a result of the alkaline-induced dissociation of the casein micelles and loss of the associated light diffusion properties $[1,2,23$, $29,36,42,44]$. This suggestion was supported by the increased proportion, in $\%$ of the total weight in milk, of $\beta$ and $\alpha_{\mathrm{s} 1}$-caseins found in the serum phase rather than in the pellet phase when analysing these fractions by RP-HPLC (not shown). The effect of $\mathrm{pH}$ on whiteness of the milk was fully reversible up to $\mathrm{pH} 8.5$ and only partially reversible at $\mathrm{pH} 9.5$ and 10.5. Particle size measurement by dynamic light scattering (not shown) confirmed that the average particle size in milk alkalinised at $\mathrm{pH} 7.5$ or 8.5 remained comparable to that found in unheated milk at pH $6.7(\sim 215 \mathrm{~nm})$ throughout treatments. Conversely, two populations of particles were observed in milk at $\mathrm{pH} 9.5$ or 10.5 , heated or not. Diameter of the smaller
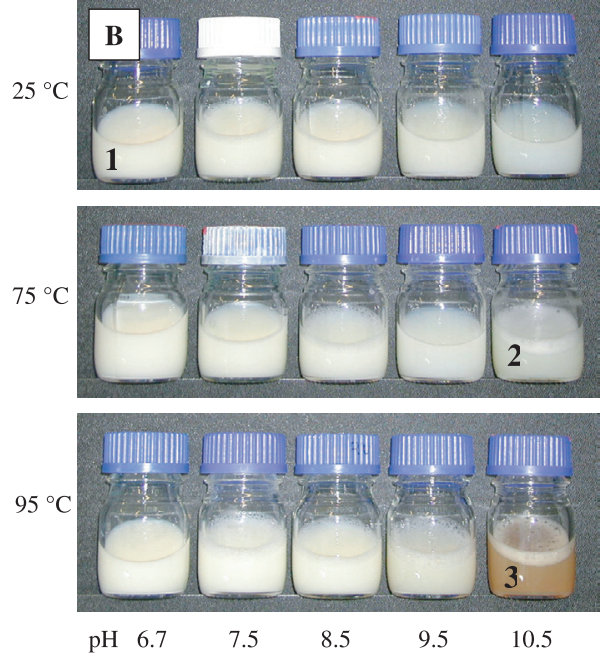
particles ranged from $300 \mathrm{~nm}$ to $1.5 \mu \mathrm{m}$, i.e. up to 7 times that of the initial average diameter of the casein micelles at $\mathrm{pH}$ 6.7. However, no sedimentation was visible. These particles were not identified. Dynamic light scattering is meant for the measurement of isolated, monomodal populations of particles in suspension; these results should therefore be taken with caution and are therefore not shown. However, these results indicated that, at least at $\mathrm{pH} 9.5$ and 10.5 , disruption and reformation of casein particles did not lead to the same protein and/or protein-mineral systems as the one initially present in the milk, despite the partial recovery of whiteness on neutralisation. The temperature of heat-treatment did not seem to have any visible effect on the recovery of whiteness or on changes in particle size on neutralisation. Direct observation of the milk samples (Fig. 2) also evidenced a large effect of the combination between high $\mathrm{pH}(\geq 9.5)$ and high temperature $\left(\geq 85^{\circ} \mathrm{C}\right)$ of heat-treatment on the development of 
orange-brown color in the milk, most likely indicating advanced Maillard reaction [33, 47]. Reformation of casein particle on neutralisation partially attenuated the brown color of milk heated at high $\mathrm{pH}$ and temperature.

Colour measurement using chromametry $\mathrm{L}^{*} \mathrm{a} \mathrm{b}^{*}$ (not shown) allowed the definition of 3 groups of samples with distinct characteristics. One first group was described with small colour coordinates, small absolutes meaning that the samples had no dominant hue; and the highest luminance $\left(\mathrm{L}^{*}\right)$ values of all samples, meaning that whiteness was dominant. This group contained samples at $\mathrm{pH} 6.7$ to 8.5 , heated or not, i.e. white milk which did not show a significant colour change or transparency change on treatment. The second group was also described by the absence of dominant hue but showed lower L* values (i.e. decreased whiteness). This group contained samples at $\mathrm{pH} 9.5$ to 10.5 heated at low temperatures, which showed partial or total disruption of the casein micelles but no browning. The last group was described by a yellowish hue and decreased whiteness (low L*). This group contained the samples submitted to a combination of high $\mathrm{pH}$ and high heating temperature. Typical samples of each group are indicated in Figure 2 as number 1,2 and 3 , respectively. These results showed that the visual observations made on the milk samples after heating were confirmed by objective measurements.

\subsection{Heat-induced protein transfers between the serum and colloidal phases of milk}

Because $\kappa$-casein and the whey proteins are the essential components of the heatinduced aggregates that form in both the serum and the micellar phases of milk, transfers of these two protein species between the two phases of milk were measured. Figure 3 shows the changes in the distribution of $\kappa$-casein and the whey proteins between the serum and micellar phases of skim milk after neutralisation, as a result of the temperature and $\mathrm{pH}$ of heat-treatment.
With these data, it is expected that the balance of the proportions of one protein between the two phases is $100 \%$. Uniform integration errors induced a slight overestimation of the whey protein area and under-estimation of the $\kappa$-casein area, as previously reported [29]. However, the $100 \%$ condition was met within $\leq 15 \%$ in most cases for the whey proteins and at low $\mathrm{pH}$ only for $\kappa$-casein. In the remaining cases, the overall balances in whey protein and/or $\kappa$-casein were significantly higher or lower than $100 \%$, suggesting that changes occurred during alkalinisation and heattreatment that affected the RP-HPLC response of the proteins. RP-HPLC areas for the whey protein in milk at $\mathrm{pH} \geq 9.5$ heated at 85 or $95^{\circ} \mathrm{C}$ were larger than usual, yielding totals higher than $120 \%$ as compared to

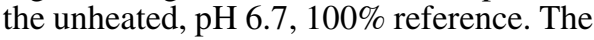
general shape of the corresponding RPHPLC profiles remained unchanged compared to that of the initial skim milk (same peaks, same retention times) but these profiles showed broad, smoothed, badly resolved peaks for all the milk proteins, especially in samples where a brown colour was observed. These changes of the RPHPLC profiles were therefore attributed to Maillard reaction, where the binding of lactose molecules to the milk proteins might account for their increased area and modified profile during HPLC separation. The fact that the whey protein, involving the Maillard sensitive $\beta$-lactoglobulin [18, 24, $34,35]$, were the only species to show an increase of their RP-HPLC area in the high $\mathrm{pH}$, high temperature conditions supported this explanation.

Conversely, RP-HPLC areas for $\kappa$ casein showed a tendency to decrease with increasing $\mathrm{pH}$ and to a lesser extent, with increasing heating temperature. Even without heat treatment, submission of the milk to $\mathrm{pH} 9.5$ or 10.5 for $3 \mathrm{~h}$ ( $2 \mathrm{~h}$ equilibration of the $\mathrm{pH}+1 \mathrm{~h}$ equilibration at $25^{\circ} \mathrm{C}$ prior to neutralisation) induced up to $21 \%$ decrease of the total $\kappa$-casein found at $\mathrm{pH} 6.7$ (Fig. 3). The same tendency was observed for $\alpha_{s 2}$ and $\beta$-caseins, but not for $\alpha_{s 1}$-casein whose area decreased markedly only at $\mathrm{pH}$ 10.5 and $95{ }^{\circ} \mathrm{C}$ (not shown). Alkaline hydrolysis of the proteins was suspected; 

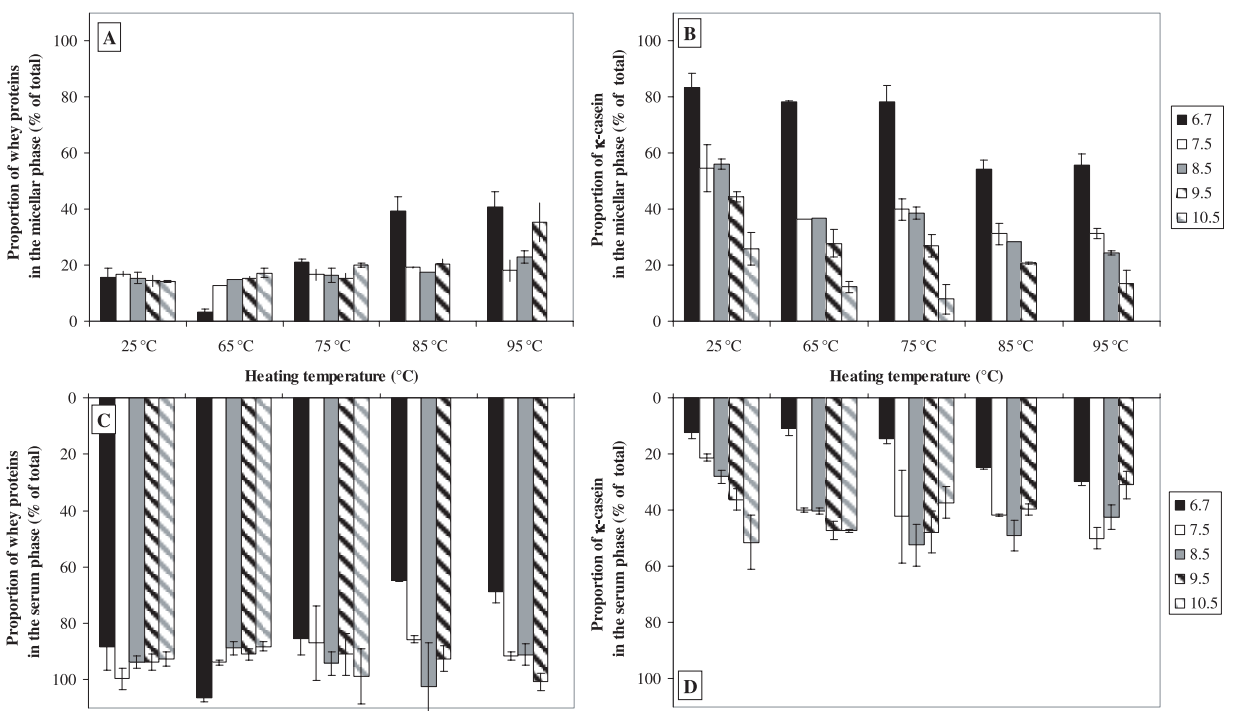

Figure 3. Distribution of the whey proteins $(A, C)$ and of the $\kappa$-casein $(B, D)$ between the ultracentrifugal pellet (A, B) and the supernatant $(\mathrm{C}, \mathrm{D})$ of skim milk adjusted at $\mathrm{pH} 6.7,7.5,8.5,9.5$ or 10.5 , heated at $25,65,75,85$ or $95^{\circ} \mathrm{C}$ for $10 \mathrm{~min}$ then neutralised to $\mathrm{pH} 6.7$ prior to ultracentrifugation. The results are given in percent of the total considered protein (total RP-HPLC area) found in the initial unheated skim milk at $\mathrm{pH}$ 6.7. The results obtained at $\mathrm{pH} 10.5$ and 85 or $95{ }^{\circ} \mathrm{C}$ were omitted because of obvious bias, as discussed in the result section.

however, Kjeldhal analysis of all the milk samples did not show any variation of the concentration in non-protein nitrogen (NPN) across $\mathrm{pH}$ nor temperature (not shown). This result thus ruled out alkaline hydrolysis as the main cause of the degradation of the milk proteins, unless this reaction was not extended enough to produce small peptides soluble in $12 \%$ trichloroacetic acid. Other possible causes are the formation of "unnatural" amino acids like lysino-alanine or lanthionine through the alkaline mediated elimination of the thiol of a cystein residue or of the organic phosphate moiety of a serine residue (both examples being particularly relevant to milk) and reaction of the dehydro-alanine protein with the $\varepsilon-\mathrm{NH}_{2}$ group of lysine of another protein $[11,15]$. However, if the crosslinked proteins are being hydrolysed to yield the release of lysino-alanine then it is expected that NPN increases in the milk; also, both $\alpha$ s 1- and $\beta$-casein have been shown to produce lysinoalanine when heated at alkaline $\mathrm{pH}$ [28] where as $\alpha_{\mathrm{s} 1}$-casein was barely affected in our conditions. Similarly, dephosphorylation under heating is common to $\alpha_{s 1^{-}}$and $\beta$-casein [25], therefore none of the listed explanations satisfactorily explained the reduction of the concentration of, especially, $\kappa$-casein in alkalinised milk, heated or not.

Despite these drawbacks, some information on the transfers of the whey proteins and $\kappa$-caseins between the serum and micellar phases of milk could be provided by the results shown in Figure 3. Figures 3A and $3 \mathrm{C}$ showed that $\mathrm{pH}$ had no effect on the distribution of the whey proteins between the two phases at heating temperature $\leq 75{ }^{\circ} \mathrm{C}$. In these conditions, $\sim 90 \%$ of the total whey proteins were consistently found in the serum phase of milk. At 85 and $95^{\circ} \mathrm{C}$ however, a significant transfer of about 20 to $30 \%$ of the total whey proteins from the 
serum to the micellar phase could be observed at $\mathrm{pH}$ 6.7, but not at higher $\mathrm{pH}$ values. These results were in accordance with Ménard et al. [29], Vasbinder and De Kruif [45], Anema and Li [3, 4] or Anema et al. [6], where the heat-induced transfer of whey proteins to the micelle phase decreased from 70 to $80 \%$ at $\mathrm{pH} 6.5, \sim 40 \%$ at $\mathrm{pH} 6.6$ and $\sim 30 \%$ at $\mathrm{pH} 6.7-6.9$ to $\sim 10 \%$ at $\mathrm{pH} 7.1$ then zero at higher $\mathrm{pH}$ values on heating milk at $90{ }^{\circ} \mathrm{C}$ for various times. However, to the authors' knowledge no data has been reported for $\mathrm{pH}$ values higher than 8.1. Figures $3 \mathrm{~B}$ and $3 \mathrm{D}$ conversely showed that the distribution of $\kappa$-casein between the two phases of milk was strongly dependent on $\mathrm{pH}$, as already suggested on observation of the clarification of milk as $\mathrm{pH}$ increased (Fig. 2). At $25{ }^{\circ} \mathrm{C}, \sim 85 \%$ of the total $\kappa$ casein of $\mathrm{pH} 6.7$ milk was found in the micellar phase, but as $\mathrm{pH}$ increased the proportion of soluble $\kappa$-casein linearly increased up to about $60 \%$ of the total $\kappa$-casein (analysable by RP-HPLC) at $\mathrm{pH}$ 10.5. On heating, the displacement of $\kappa$ - casein from the micelle phase was further increased. In milk at pH 6.7, no change in the distribution was observed until a temperature of 85 or $95^{\circ} \mathrm{C}$ was used, where 10 to $20 \%$ of the total $\kappa$-casein were transferred from the micellar to the serum phase, yielding $\sim 30 \%$ of the total $\kappa$-casein in the serum phase. These figures were in accordance with the data reported by Anema and Klostermeyer [1] and Anema and Li [2] where the proportion of non-sedimentable $\kappa$-casein increased from $15 \%$ in unheated milk to $20 \%$ at $60{ }^{\circ} \mathrm{C}$ and $25-30 \%$ at $90{ }^{\circ} \mathrm{C}$ for various heating times. In milk at $\mathrm{pH} 7.5$ or above, a heat-induced transfer of $\kappa$ casein from the micellar to the serum phase could be observed at temperatures as low as $65^{\circ} \mathrm{C}$ but extent of the transfer was then rather constant across heating temperatures. At $\mathrm{pH} 7.5$, the proportion of the total "RP-HPLC analysable" $\kappa$-casein in the micellar phase was $73 \%$ at $25^{\circ} \mathrm{C}$ and $47 \%$ after heat-treatment at $65^{\circ} \mathrm{C}$; similarly, this proportion decreased from 33 to $17 \%$ at $\mathrm{pH}$ 10.5 . About 15 to $25 \%$ of $\kappa$-casein therefore dissociated from the micellar phase as a result of heating at temperature $\geq 65^{\circ} \mathrm{C}$ and $\mathrm{pH} \geq 7.5$. Of course, these calculations were made with the assumption that the alkaline degradation of $\kappa$-casein is proportional in the two phases of milk, therefore that the total "RP-HPLC analysable" $\kappa$ casein is distributed between the micellar and serum phases in the same proportions as before protein loss. Despite the poor quality of the results, they were in accordance with previous reports where a positive relationship was demonstrated between the $\mathrm{pH}$ of heat-treatment and the extent of the heat-induced dissociation of $\kappa$-casein $[1,2,42]$, albeit the latter was also found to increase with temperature in milk at $\mathrm{pH} 6.9$ or 7.1 [1, $2]$. The latter studies found about $30 \%$ more $\kappa$-casein in the serum of milk heated at $\mathrm{pH} 7.1$ and $90^{\circ} \mathrm{C}$ than at $\mathrm{pH} 7.1$ and $20^{\circ} \mathrm{C}$. Singh and Creamer [42] found 40 to $50 \%$ more $\kappa$-casein in the serum of concentrated milk at $\mathrm{pH} 6.85$ after heat-treatment at $120{ }^{\circ} \mathrm{C}$ for a few min.

These results showed that, starting from a reference situation where $\kappa$-casein and the whey proteins are largely separated between the two phases of unheated, $\mathrm{pH} 6.7$ skim milk, both alkaline and to a lesser extent heat-treatment favoured the contact of the two protein species. On alkalinisation, $\kappa$-casein was transferred from the micellar to the serum phase; this transfer was further enhanced by heating and yielded the colocation of the two protein species in the serum phase. At $\mathrm{pH}$ 6.7, heat-treatment induced the exchange of $\kappa$-casein and the whey protein, yielding a co-location of the two protein species in both the serum and micellar phases. In earlier reports, it has been proposed that the heat-induced colocation of $\kappa$-casein and the whey proteins suggested that thiol-disulfide exchanges and aggregate formation had occurred between the two protein species on heating [3, $4,6,29]$. For $\mathrm{pH}$ values higher than 8, Monahan et al. [32] or Connolly [8] have shown that thiol-disulfide exchanges and aggregate formation could occur even at low heating temperature. However, in the present study disruption of the casein micelle at these $\mathrm{pH}$ and forced co-location of the caseins with the whey proteins as shown in Figure 3 did not provide enough indication of the formation of serum aggregates in these conditions. 


\subsection{Separation of the heat-induced serum protein aggregates and dissociated casein using SE-FPLC}

The serum phase of the milk samples was analysed by SE-FPLC as a means to identify their components. Protein composition of the eluted peaks was analysed by RP-HPLC. The results are shown in Figure 4. For the sake of clarity, only those obtained at 25,75 and $85^{\circ} \mathrm{C}$ are shown. The profiles obtained at $65^{\circ} \mathrm{C}$ were intermediate to those obtained at 25 and $75{ }^{\circ} \mathrm{C}$. The profiles obtained at $95^{\circ} \mathrm{C}$ were very similar to those obtained at $85{ }^{\circ} \mathrm{C}$, and were not chosen because of the poor quality of the $\mathrm{RP}-\mathrm{HPLC}$ results obtained at this $\mathrm{pH}$.

Previous reports [19, 37] have shown that the protein fraction of the serum phase eluted between 130 min (exclusion peak) and $330 \mathrm{~min}$. The material eluting at longer times is non-protein and was not considered in the present study.

The results showed that two different behaviours were obtained depending on the heating temperature of the milk. At 25, 65 and $75^{\circ} \mathrm{C}$, the protein material was separated in 3 poorly resolved peaks respectively eluting at $\sim 250,270$ and $300 \mathrm{~min}$ (Figs. 4A and 4B). At $25^{\circ} \mathrm{C}$ and pH 6.7-8.5, only the two peaks at 250 and 300 min were present. Analyses of the corresponding fractions by RP-HPLC showed that these peaks respectively contained small casein particles, with a high proportion of $\kappa$ casein, and native whey protein with some casein monomers. These results were in accordance with Guyomarc'h et al. [19] and Ménard et al. [29]. As pH increased, a third peak developed in the 270 min region, as also reported by Donato and Dalgleish [13] and Ménard et al. [29] in unheated milk. This peak contained a high proportion of $\alpha_{s^{-}}$ and $\beta$-caseins and was identified as another type of small casein particles. This is also where sodium caseinate is eluted [37]. As $\mathrm{pH}$ increased from 6.7 to 10.5 , the areas of the two peaks of small casein particles, i.e., eluting at 250 and $270 \mathrm{~min}$, increased slightly up to $\mathrm{pH} 8.5$ then dramatically up to $\mathrm{pH} 10.5$, where reduction of the resolution induced fusion of the constitutive peaks (Fig. 4A). This result evidenced the alkaline-induced dissociation of the casein micelle. At pH 7.5 to 9.5, dissociation of the casein micelle in the form of $\kappa$-casein-rich and $\alpha_{\mathrm{s}} / \beta$-casein small particles increased as a function of temperature up to $75{ }^{\circ} \mathrm{C}$. Barely any change was observed at $\mathrm{pH} 6.7$ (little or no dissociation) and pH 10.5 (advanced disruption of the micelles even at $25^{\circ} \mathrm{C}$ ) across temperature. Figure 4B also showed that the area of the peak containing the native whey protein (at $300 \mathrm{~min}$ ) seemed to decrease as $\mathrm{pH}$ increased as a result of heating at $65^{\circ} \mathrm{C}$ (not shown) or $75^{\circ} \mathrm{C}$ (Fig. 4B). Composition of the eluate fractions showed that higher proportions of $\kappa$-casein and whey proteins were then coeluted with the $\alpha_{s} / \beta$-casein fraction at $270 \mathrm{~min}$. These proportions tended to increase with $\mathrm{pH}$ (not shown). Despite the low temperature, these results indicated that small quantities of $\kappa$-casein and whey protein were found together at retention times lower than that of protein monomers, therefore possibly forming small complexes. However, it was not possible to know whether the composition of the $\alpha_{s} / \beta$ casein particle changed or whether new, heat-induced particles were formed in the serum on heating milk and co-eluted with them. On heating at 85 or $95{ }^{\circ} \mathrm{C}$, the SEFPLC profiles changed significantly (Fig. 4C). Area of the native protein peak (at $300 \mathrm{~min}$ ) decreased as $\mathrm{pH}$ decreased, with dramatic heat-induced reduction at $\mathrm{pH} 6.7,7.5$ and 8.5 , and little or no heat-induced change at pH 9.5 and 10.5. A new peak concomitantly appeared at short elution times, e.g. $215 \mathrm{~min}$ for heat-treatment at $\mathrm{pH} 6.7$ and $85^{\circ} \mathrm{C}$, evidencing the formation of large particles. RP-HPLC analysis showed that this fraction was essentially composed of whey protein and $\kappa$-casein, which was interpreted as the formation of heat-induced whey protein/K-casein aggregates $[13,19,37,40]$. Elution time of this heat-induced peak increased with increasing $\mathrm{pH}$, showing that smaller whey protein/K-casein aggregates were formed at higher $\mathrm{pH}$, in accordance with the reports by Donato and Dalgleish [13], Vasbinder and De Kruif [45], Renan et al. [39], Hoffmann et al. [21] or Ménard et al. [29]. At pH 9.5 and 10.5, poor resolution 

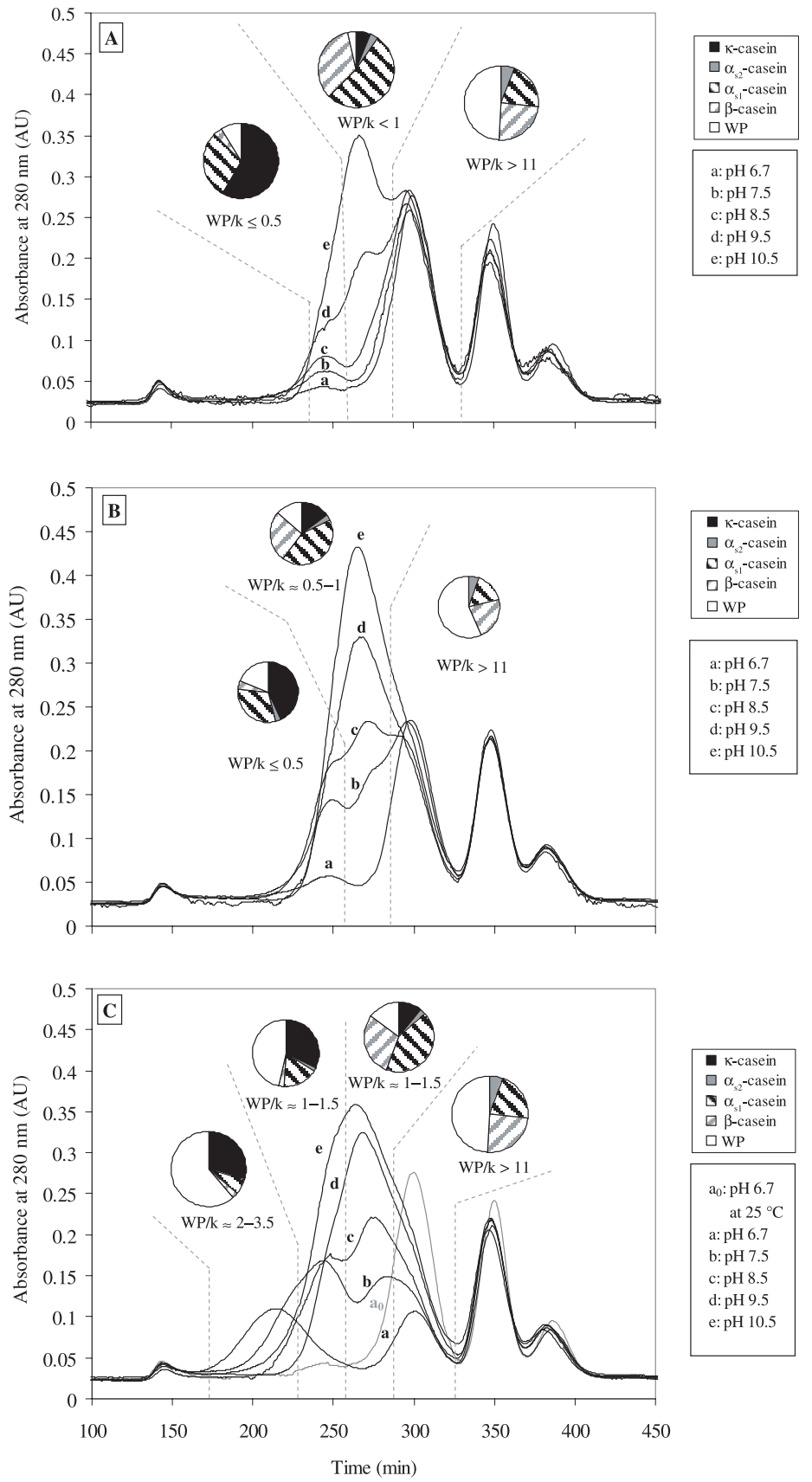

Figure 4. Typical SE-FPLC profiles of the ultracentrifugal supernatants of skim milk adjusted at $\mathrm{pH} 6.7,7.5,8.5,9.5$ or 10.5 , heated at $25^{\circ} \mathrm{C}(\mathrm{A}), 75^{\circ} \mathrm{C}(\mathrm{B})$ or $85^{\circ} \mathrm{C}(\mathrm{C})$ for $10 \mathrm{~min}$ prior to ultracentrifugation. The inserted pie-charts show the typical protein composition, in $\%$ of the total RPHPLC area, of the eluate fractions collected as shown by the dotted lines. 
of the various types of small protein particles made interpretation difficult; however, elution of the merged peaks seemed to start from lower elution times at 85 and $95{ }^{\circ} \mathrm{C}$ than at lower heating temperatures. Composition of the corresponding fraction, at about $250 \mathrm{~min}$, showed that whey proteins and $\kappa$-casein were present in high proportions (Fig. 4C), thus indicating that small whey protein/ $\kappa$-casein aggregates were probably formed that co-eluted with the larger alkaline-dissociated casein material.

The results shown in Figure 4 therefore evidenced two different behaviours of the whey proteins in response to heat and alkaline treatment of milk. At low temperature $\left(\leq 75^{\circ} \mathrm{C}\right)$ and high $\mathrm{pH}$ values $(\geq 9.5)$, some native whey proteins seemed to be lost and indications of the formation of small whey protein/ $\kappa$-casein aggregates could be detected in the 250 -min region. These changes slightly increased with increasing temperature up to $95^{\circ} \mathrm{C}$. At low $\mathrm{pH}$ values (6.7-8.5), high temperatures of heat-treatment (85$95^{\circ} \mathrm{C}$ ) were necessary for significant formation of serum aggregates; and the lower the $\mathrm{pH}$, the larger the aggregates. This agreed with the results shown in Figure 3 for $\mathrm{pH} 6.7$ milk, where significant heatinduced changes in the protein transfers between the serum and the micellar phases were only significant at 85 or $95^{\circ} \mathrm{C}$. However, determination of the denaturation rate of the whey protein using Kjeldahl analysis of the nitrogen fractions of milks at $\mathrm{pH} 6.7$ and 10.5 (not shown) showed that denaturation was $\sim 40 \%$ of the total native whey protein after heating at $75^{\circ} \mathrm{C}$ at $\mathrm{pH} 6.7$ and increased up to $74 \%$ at $95{ }^{\circ} \mathrm{C}$, while heattreatment at $\mathrm{pH} 10.5$ yielded $7 \%$ denaturation at $25{ }^{\circ} \mathrm{C}, 55 \%$ at $65{ }^{\circ} \mathrm{C}$ and 62 to $72 \%$ at higher temperatures. This indicated that denaturation of the whey protein occurred at lower temperature when $\mathrm{pH}$ was strongly alkaline, in accordance with Monahan et al. [33], and supported the hypothesis that small disulfide complexes could be formed in these conditions. The fact that the SEFPLC profiles of the serum of milk at $\mathrm{pH}$ 9.5 and 10.5 only slightly changed on heating at temperature 75 to $95^{\circ} \mathrm{C}$, where as aggregate formation at $\mathrm{pH} \leq 8.5$ was enhanced at 85 and $95{ }^{\circ} \mathrm{C}$ and increased as heat load increased might indicate different types of heat-induced protein complexes.

\subsection{Properties of the acid gels}

The wanted characteristics of acid milk gels like set yoghurt are gelation at high $\mathrm{pH}$ value, high elasticity (firmness) and low syneresis. The two first characteristics are well measured using low amplitude oscillation rheology throughout acidification of the milk. The gel point, or gelation $\mathrm{pH}$, is defined as the $\mathrm{pH}$ value when $\mathrm{G}^{\prime}>1 \mathrm{~Pa}$. Final $\mathrm{G}^{\prime}$ is taken at $\mathrm{pH} 4.6$, as about the $\mathrm{pH}$ value when the gel is cooled down and/or stirred in yoghurt manufacture. However, even 5 or more $h$ after the gelation point, G' was still slightly increasing with time, i.e., the gels were not totally stable. This ability of acid milk gels to indefinitely rearrange well after gelation is well known [48]. Care should therefore be taken in interpreting the results, although it is likely that differences observed at $\mathrm{pH} 4.6$ between two milk systems would be maintained on longer times. The rate of gelation is $\mathrm{dG}^{\prime} / \mathrm{dpH}$, in $\mathrm{Pa} \cdot \mathrm{min}^{-1}$, i.e. the slope of the increase in $G$ ' from the gelation point onwards.

Figure 5 shows the increase in elastic modulus, $\mathrm{G}^{\prime}(\mathrm{Pa})$, as a function of $\mathrm{pH}$ after addition of GDL to the neutralised milk samples. The results show that the acid gels formed with unheated (i.e. kept at $25^{\circ} \mathrm{C}$ ) milk samples only reached elastic modulus values, G', lower than $20 \mathrm{~Pa}$ at $\mathrm{pH} 4.6$ and were therefore very soft gels. The inability of unheated milk to form elastic gel is widely reported in the literature $[20,26$, 27]. However, unheated milk at $\mathrm{pH} 6.7$ started acid gelation at higher $\mathrm{pH}$ values and reached higher G' values than all the other milks. This result could be explained by changes in the structure of the casein micelle on $\mathrm{pH}$ cycle (see Sect. 3.1), dilution of the milks by addition of $\mathrm{NaOH}$ and $\mathrm{HCl}$ or loss of the functionality of the proteins due to $\mathrm{pH}$-induced changes as discussed in Section 3.2. When the milk had been heated at 65 or $75^{\circ} \mathrm{C}$ at $\mathrm{pH} 9.5$ or 10.5 , higher gelation $\mathrm{pH}$ and final $\mathrm{G}$ ' values were found compared to milk heated at $\mathrm{pH}$ 6.7-8.5. Final G' values of $160 \mathrm{~Pa}$, i.e., about half that of skim milk at pH 6.7 heated at 85 or $95^{\circ} \mathrm{C}$, could for instance be reached by milk 

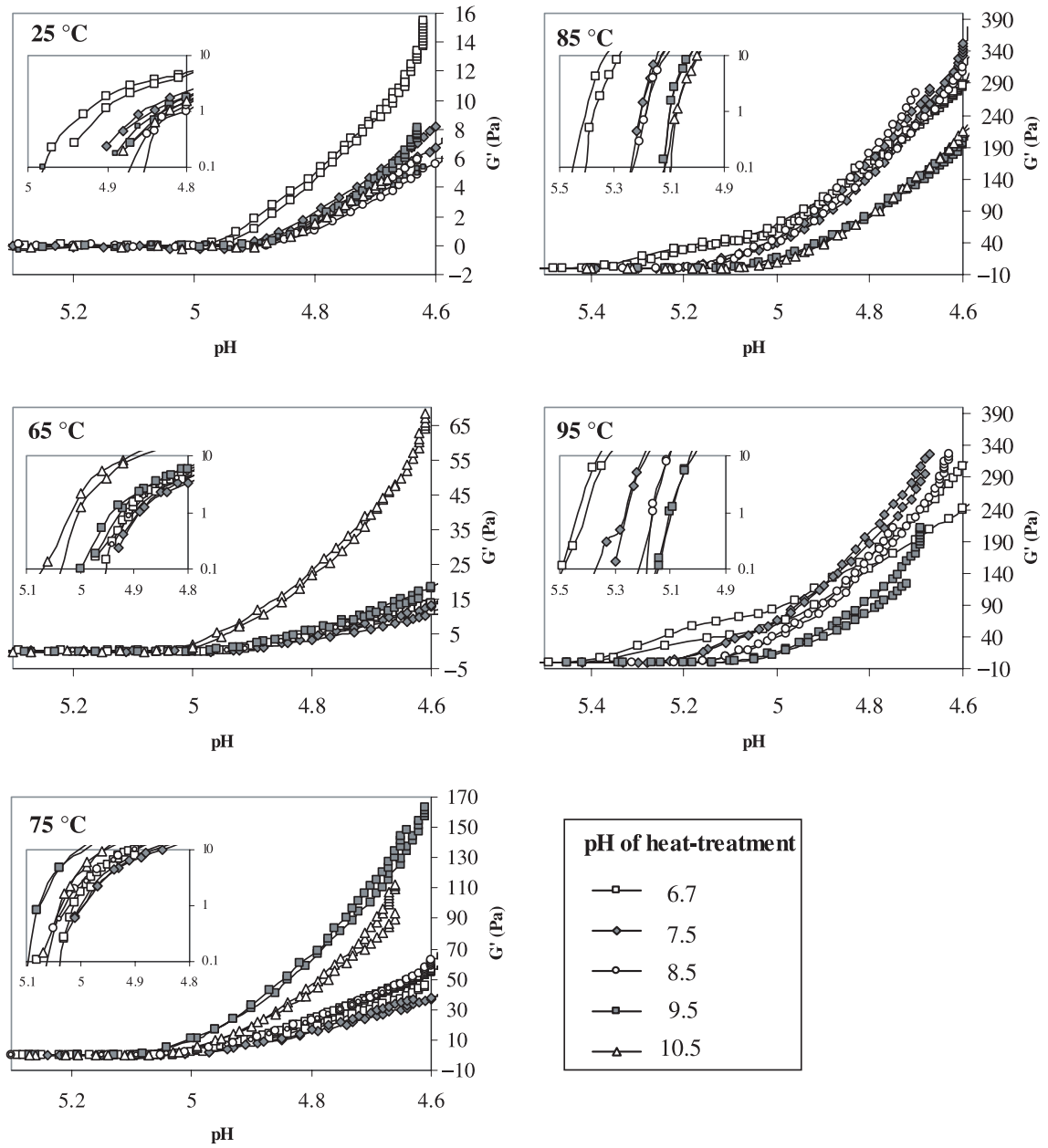

Figure 5. Typical acid gelation profiles of skim milk adjusted at $\mathrm{pH} 6.7,7.5,8.5,9.5$ or 10.5 , heated at $25,65,75,85$ or $95^{\circ} \mathrm{C}$ for $10 \mathrm{~min}$, neutralised to $\mathrm{pH} 6.7$ then acidified to $\mathrm{pH} 4.6$ at $38{ }^{\circ} \mathrm{C}$ by addition of $11 \mathrm{~g} \cdot \mathrm{L}^{-1} \mathrm{GDL}$ and measurement by low amplitude oscillation rheometry. The inserted figures (with $G^{\prime}$ in $\log$ scale) focus on the gel point $\left(\mathrm{G}^{\prime}>1 \mathrm{~Pa}\right)$ of the milk samples.

heated at $\mathrm{pH} 9.5$ at as low a temperature as $75^{\circ} \mathrm{C}$. However, the positive effect of high $\mathrm{pH}$ of heat-treatment on gel formation seemed to be cancelled out when higher temperatures of heat-treatment were used. After heat-treatment at 85 or $95^{\circ} \mathrm{C}$, highest gelation $\mathrm{pH}$ values of $\sim 5.4$ were obtained with milk at $\mathrm{pH} 6.7$, and decreased to $\mathrm{pH}$ $\sim 5.1$ as the $\mathrm{pH}$ of heat-treatment increased.
However, the rate of gel formation seemed to be slightly lower at $\mathrm{pH} 6.7$ than at $\mathrm{pH} 7.5$ and 8.5. The final G' values obtained at the latter $\mathrm{pH}$ values were therefore slightly higher than those obtained at $\mathrm{pH} 6.7\left(P_{0}>\right.$ 0.05 , not significant). Despite a low $\mathrm{pH}$ of gelation of 5.1, milk heated at $\mathrm{pH} 10.5$ and $95^{\circ} \mathrm{C}$ showed a higher gel formation rate than that of the other milks heated at $95^{\circ} \mathrm{C}$ and 
final G' values up to $340 \mathrm{~Pa}$ on acidification (not shown for reason of clarity). Since the ability of milk heated at $\mathrm{pH} 10.5$ to form early and firm acid gels decreased with temperature from 65 to $85^{\circ} \mathrm{C}$, this result was rather surprising and remained unexplained.

It should be mentioned that despite standardised acidification conditions not all samples reached $\mathrm{pH} 4.6$ after $8 \mathrm{~h}$ of analysis. For instance, the final $\mathrm{pH}$ of unheated skim milk at $\mathrm{pH} 6.7$ or of skim milk heated at $\mathrm{pH} 10.5$ and $75^{\circ} \mathrm{C}$ tended towards 4.65 (Fig. 5). In general, it seemed that higher final $\mathrm{pH}$ values were observed when earlier and stronger gels were formed. This may be accounted for by differences in proton diffusion and/or performances of the $\mathrm{pH}$ probe depending on the gel properties.

As suggested by the results of Figure 4, formation of these acid milk gels depended on the heating temperature and $\mathrm{pH}$. At low temperatures $\left(65-75{ }^{\circ} \mathrm{C}\right)$, milk samples heated at $\mathrm{pH} 9.5$ and 10.5 showed enhanced gelation properties while milk samples heated at lower $\mathrm{pH}$ values showed poor acid gelation properties. At high temperatures $\left(\geq 85^{\circ} \mathrm{C}\right)$, acid gelation properties of the milks heated at $\mathrm{pH} 9.5$ or 10.5 decreased where as milk samples heated at pH 6.7-8.5 showed the highest gelation properties. To the authors' knowledge, no data is available on the acid gelation behaviour of skim milk heated at $\mathrm{pH}$ higher than 7.5. In the range 6.7-7.1, various studies conclusively reported a positive relationship between the $\mathrm{pH}$ of heat-treatment at 80 or $90{ }^{\circ} \mathrm{C}$ and an onset of gelation at higher $\mathrm{pH}$ values as well as higher gel strength of the acid gel [5, 40, 45]. The present study showed that the positive effect of alkaline $\mathrm{pH}$ values of heattreatment on the increase of the final gel strength of acid gels could be partially and marginally extended up to $\mathrm{pH}$ 8.5. Some limitation of this increase therefore existed, as suspected by Rodriguez del Angel and Dalgleish [40] who observed a decrease of the final gel strength of acid gels after heating at $\mathrm{pH}$ 7.2. Another original result of this study was that significant $\left(P_{0}<0.05\right)$ ability to acid gelation could be obtained by heattreating milk at $75^{\circ} \mathrm{C}$, providing that $\mathrm{pH}$ was $\geq 9.5$.

\section{DISCUSSION}

In this study, heat-treatment of skim milk at various $\mathrm{pH}$ values up to 10.5 was experimented as an attempt to reduce the heat load necessary to form whey protein/ $/$ casein aggregates and/or to enhance the acid gelation properties of heated skim milk by displacing these aggregates to the serum phase. The results indicated that the heatinduced transfer of the whey proteins from the serum to the micellar phase was inhibited at $\mathrm{pH} 7.5$ or higher, while the transfer of the $\kappa$-casein from the micellar to the serum phase was increased on increasing $\mathrm{pH}$, even at low heating temperature (Fig. 3). These results were in accordance with those obtained by Ménard et al. [29] and suggested that alkaline $\mathrm{pH}$ up to about 7.5-8.0 was enough to prevent formation of micellebound whey protein/ $\kappa$-casein aggregates. The fact that little extra dissociation of $\kappa-$ casein was induced by heat-treatment at $\mathrm{pH}$ $\geq 7.5$ and temperature $\geq 65^{\circ} \mathrm{C}$ where as no whey proteins were transferred to the colloidal phase in the meantime suggested that formation of the serum aggregates involved the alkaline dissociated $\kappa$-casein and that a limitation may exist in the quantity of serum aggregates possibly formed with $\kappa$ casein and whey proteins in the proportions found in milk. Conversely, the fact that some heat-induced dissociation of $\kappa$-casein did occur at $\mathrm{pH} \geq 7.5$ and temperature $\geq 65^{\circ} \mathrm{C}$ in spite of the availability of extensively alkaline-dissociated $\kappa$-casein (Fig. 3B/ $\mathrm{D}, 25^{\circ} \mathrm{C}$ ) also suggested that formation of the serum whey protein/ $\kappa$-casein aggregates probably involved both the micellebound and dissociated $\kappa$-casein forms. This conclusion may be compared to that of Donato et al. (unpublished results), who observed that soluble $\kappa$-casein added to skim milk at $\mathrm{pH} 6.7$ was not involved in the formation of aggregates on heating and concluded that a competitive route for the formation of serum aggregates was through the interaction of the denatured whey protein with $\kappa$ casein on the surface of the casein micelle.

Beyond indications of the formation and distribution of the heat-induced whey protein/ $\kappa$-casein aggregates, as the scope of the present study, the mass balances showed in 
Figure 3 also raised questions on the nature of the changes experienced by the milk system when submitted to high alkaline $\mathrm{pH}$ conditions. On heating milk at $\mathrm{pH} 10.5$ and $65{ }^{\circ} \mathrm{C}$ for instance, the proportion of the total $\kappa$-casein that was found in the micellar phase did not exceed $20 \%$ after neutralisation. Yet, no visible precipitation of the reassociated "casein micelles" occurred in the milk samples (Fig. 2). The reduced opacity of the milks heated at $\mathrm{pH} 9.5$ or 10.5 and neutralised, compared to that of control milk; the occurrence of light scattering particles smaller than casein micelles in these neutralised samples and the small size of the pellet obtained on centrifugation of the same samples suggested that most of the particles formed on neutralisation of milk samples previously heated at $\mathrm{pH} 9.5-10.5$ remained in the supernatant, hence the low proportion of "micellar" $\kappa$-casein in these samples.

Similarly, visible precipitation of insoluble calcium phosphate could have been expected on heating milk at alkaline $\mathrm{pH}$, e.g. on the walls of the Schott bottles. Both alkaline $\mathrm{pH}$ values $[22,44]$ and heat-treatment [38] induce the reduction of the concentrations in soluble calcium and phosphate ions. Whether the transfer of calcium and phosphate ions to the colloidal phase of milk is through the actual interaction with casein (growth of the calcium phosphate nanoclusters [22]) or through the formation of mineral crystals as in alkalinised whey [14] or both, is unclear. Vaia et al. [44] attributed the dissociation of the casein micelle on alkalinisation to the fact that depletion of the solvent phase in calcium ions probably increased the amount of free water and therefore solvent quality, hence solvatation of the calcium-sensitive casein molecules. Also, the occurrence of some large particles ( $\mu \mathrm{m}$ range) in the alkalinised or neutralised milks as observed in the present study using light scattering may be accounted for by some mineral precipitation. However, Odagiri and Nickerson [36] reported that neutralisation of skim milk submitted to $\mathrm{pH}$ values up to 11 for $3 \mathrm{~h}$ did not induce changes in the calcium phosphate distribution in the milks, showing that changes are probably very slow. This may explain why no extensive mineral precipitation had been observed in the present study.

On heat-treatment of skim milk at low temperature $\left(65-75^{\circ} \mathrm{C}\right)$ and high $\mathrm{pH}$ values (9.5-10.5), the results obtained by SE-FPLC (Fig. 4) seemed to indicate the formation of serum whey protein/א-casein aggregates that probably accounted for the significant increase in gelation $\mathrm{pH}$ and final gel strength obtained with these milks compared to that of the pH 6.7 control (Fig. 4). These results agreed with Monahan et al. [32] and Connolly [8] who used similar conditions to induce thiol/disulfide exchanges between globular proteins. However, present results showed that this combination of treatments did not produce acid gels whose gel strength could compete with those obtained from classically heated (85-95 ${ }^{\circ} \mathrm{C}, 5-10 \mathrm{~min}$ ) skim milk at pH 6.7. On heat-treatment of skim milk at 85 or $95^{\circ} \mathrm{C}$, serum whey protein/ $\mathrm{K}$-casein aggregates could be formed at all $\mathrm{pH}$ values (Fig. 4) and acid gels showed higher final gel strength values (Fig. 5). However, the $\mathrm{pH}$ of gelation tended to decrease as the $\mathrm{pH}$ of heat-treatment increased, and only milk heated at $\mathrm{pH}$ 7.5-8.5 showed final gel strength marginally higher than at $\mathrm{pH}$ 6.7. Limitation or inhibition of the increase in gelation $\mathrm{pH}$ and final strength of acid gels made with milk heated at alkaline $\mathrm{pH}$, i.e., having high proportion of serum aggregates $[5,40,45]$ might be accounted for by various reasons. First, changes in the properties of the casein micelles might have occurred. Reorganisation of the caseins on $\mathrm{pH}$ cycling and changes in size distribution (see Sect. 3.1) might have affected the homogeneity of acid gels. Partial precipitation or other changes in the calcium phosphate equilibrium on heating at high $\mathrm{pH}$ and neutralisation might have also affected the ability of the casein micelle to acid gelation. Dialysis of skim milk against milk ultrafiltrate to reduce the total concentration in calcium and phosphate, followed by heattreatment of the milk induces changes in the casein organisation (partial solubilisation, decreased zeta potential) and yields acid gels with variable $\mathrm{pH}$ of gelation and generally decreased final elasticity (Famelart, personnal communication). Also, the binding 
of lactose on casein molecules on Maillard reaction could change their electrostatic properties and hence increase solubility of the casein micelles [10], thus possibly decreasing their ability to aggregation and gelation. Second, there may be a limitation for the size of the heat-induced whey protein/ $\kappa$-casein aggregates below which their effect on texture formation is reduced, i.e., aggregates formed at $\mathrm{pH} \geq 9.5$ may be too small to act as fillers or to significantly affect growth and branching of the protein strands in the gel. Finally, it is very likely that degradation of the milk protein as observed in Figure 3, either by extensive Maillard reaction or by other reactions affecting caseins, affected gel formation through reduction of the actual concentration of proteins able to form an acid gel after heattreatment at $\mathrm{pH} \geq 9.5$ and high temperature. These drawbacks have not been reported in any of the previous reports using high $\mathrm{pH}$ and heat-treatment of milk or whey [7, 16] or $\mathrm{pH} 12$ for up to $2 \mathrm{~h}$ at room temperature [23]. Considering the improvement of the gelation properties of milk samples treated in milder conditions (high $\mathrm{pH}$ and low heating temperature or high heating temperature and moderate alkaline $\mathrm{pH}$ ) and considering the results of Monahan et al. [32] for solutions of WPI in water, it could be interesting to perform high heat-treatment on delactosed skim milk or on a mixture of caseinate and whey protein in lactose-free medium, adjusted at high $\mathrm{pH}$ values to know whether such improvement does not occur at high $\mathrm{pH} /$ high temperature or whether it is counter-balanced by effects of the Maillard reaction. However, such processes would only have scientific interest since a possible reduction of the heatload necessary to improve ability of heated milk to acid gelation would not, or barely, cover the cost of preliminary diafiltration or drying of the casein and WPI ingredients.

Acknowledgements: This work has received the financial support of the Brittany Local Council (Conseil de la Région Bretagne) and of the French Government Local Office in Brittany (Préfecture de la Région Bretagne) under the grant 2005-20. Authors are very grateful to Florence Rousseau for dynamic light scattering analyses.

\section{REFERENCES}

[1] Anema S.G., Klostermeyer H., Heat-induced, $\mathrm{pH}$-dependent dissociation of casein micelles on heating reconstituted skim milk at temperatures below $100{ }^{\circ} \mathrm{C}$, J. Agric. Food Chem. 45 (1997) 1108-1115.

[2] Anema S.G., Li Y., Further studies on the heat-induced, $\mathrm{pH}$-dependent dissociation of casein from the micelles in reconstituted skim milk, Lebensm.-Wiss. Technol. 33 (2000) 335-343

[3] Anema S.G., Li Y., Association of denatured whey proteins with casein micelles in heated reconstituted skim milk and its effect on casein micelle size, J. Dairy Res. 70 (2003) 73-83.

[4] Anema S.G., Li Y., Effect of pH on the association of denatured whey proteins with casein micelles in heated reconstituted skim milk, J. Agric. Food Chem. 51 (2003) 16401646.

[5] Anema S.G., Lee S.K., Lowe E.K., Klostermeyer H., Rheological properties of acid gels prepared from heated $\mathrm{pH}$-adjusted skim milk, J. Agric. Food Chem. 52 (2004) 337-343.

[6] Anema S.G., Lowe E.K., Lee S.K., Effect of $\mathrm{pH}$ on the acid-induced aggregation of casein micelles in reconstituted skim milk, Lebensm.-Wiss. Technol. 37 (2004) 779-787.

[7] Blazey N.D., Knights R.J., Wu C., Membrane filtered milk proteins varying in composition and functional attributes, Patent WO00/51440, 2000

[8] Connolly P.B., Method of producing milk protein isolates and milk protein/vegetable protein isolates and compositions of same, Patent WO82/01641, 1982.

[9] Corredig M., Dalgleish D.G., The mechanisms of the heat-induced interaction of whey proteins with casein micelles in milk, Int. Dairy J. 9 (1999) 233-236.

[10] Courthaudon J.-L., Colas B., Lorient D., Covalent binding of glycosyl residues to bovine caseins: effects on solubility and viscosity, J. Agric. Food Chem. 37 (1989) 32-36.

[11] de Koning P.J., van Rooijen P.J., Aspects of the formation of lysinoalanine in milk and milk products, J. Dairy Res. 49 (1982) 725736.

[12] de la Fuente M.A., Singh H., Hemar Y., Recent advances in the characterisation of heat-induced aggregates and intermediates of whey proteins, Trends Food Sci. Technol. 13 (2002) 262-274. 
[13] Donato L., Dalgleish D.G., Effect of the pH of heating on the qualitative and quantitative compositions of the sera of reconstituted skim milks and on the mechanisms of formation of soluble aggregates, J. Agric. Food Chem. 54 (2006) 7804-7811.

[14] Fauquant J., Pierre A., Brulé G., Clarification de lactosérum acide de caséinerie, Technol. Lait. 1003 (1985) 37-41.

[15] Friedman M., Chemistry, biochemistry, nutrition, and microbiology of lysinoalanine, lanthionine, and histidinoalanine in food and other proteins, J. Agric. Food Chem. 47 (1999) 1295-1319.

[16] Grufferty M.B., Mulvihill D.M., Proteins recovered from milks heated at alkaline $\mathrm{pH}$ values, J. Soc. Dairy Technol. 40 (1987) 8285.

[17] Grufferty M.B., Mulvihill D.M., Hydration related properties of protein isolates prepared from heated milks, J. Soc. Dairy Technol. 43 (1990) 99-103.

[18] Guyomarc'h F., Warin F., Muir D.D., Leaver J., Lactosylation of milk proteins during the manufacture and storage of skim milk powders, Int. Dairy J. 10 (2000) 863 872.

[19] Guyomarc'h F., Law A.J.R., Dalgleish D.G., Formation of soluble and micelle-bound protein aggregates in heated milk, J. Agric. Food Chem. 51 (2003) 4652-4660.

[20] Guyomarc'h F., Quéguiner C., Law A.J.R., Horne D.S., Dalgleish D.G., Role of the soluble and micelle-bound heat-induced protein aggregates on network formation in acid skim milk gels, J. Agric. Food Chem. 51 (2003) 7743-7750.

[21] Hoffmann M.A.M., Sala G., Olieman C., De Kruif K.G., Molecular mass distributions of heat-induced beta-lactoglobulin aggregates, J. Agric. Food Chem. 45 (1997) 2949-2957.

[22] Holt C., Biophysique des sels et de la micelle de caséines, in: Gaucheron F. (Ed.), Minéraux et produits laitiers, Tec et Doc Lavoisier, Paris, France, 2004, pp. 113-149.

[23] Leaver J., Law A.J.R., Milk and cheese modification process, including methods of extracting beta-lactoglobulin and caseins from milk and milk products, and novel products thereby produced, Patent WO01/ 52665, 2001.

[24] Léonil J., Mollé D., Fauquant J., Maubois J.-L., Pearce R.J., Bouhallab S., Characterization by ionization mass spectrometry of lactosyl $\beta$-lactoglobulin conjugates formed during heat treatment of milk and whey and identification of one lactose-binding site, J. Dairy Sci. 80 (1997) 2270-2281.

[25] Lorient D., Alais C., Dégradation thermique des caséines alpha-s et beta de vache. 1-Facteurs de variation de la dégradation, Bull. Soc. Chim. Biol. 52 (1970) 915-926.

[26] Lucey J.A., Singh H., Formation and physical properties of acid milk gels: a review, Food Res. Int. 30 (1998) 529-542.

[27] Lucey J.A., Teo C.T., Munro P.A., Singh H., Rheological properties at small (dynamic) and large (yield) deformations of acid gels made from heated milk, J. Dairy Res. 64 (1997) 591-600.

[28] Manson W., Carolan T., Formation of lysinoalanine from individual bovine caseins, $\mathrm{J}$. Dairy Res. 47 (1980) 193-198.

[29] Ménard O., Camier B., Guyomarc'h F., Effect of heat-treatment at alkaline $\mathrm{pH}$ on the rennet coagulation properties of skim milk, Lait 85 (2005) 515-526.

[30] Mleko S., High-pH gelation of whey protein isolate, Int. J. Food Sci. Technol. 36 (2001) 331-334.

[31] Mollé D., Jean K., Guyomarc'h F., Chymosin sensitivity of the heat-induced serum protein aggregates isolated from skim milk, Int. Dairy J. 16 (2006) 1435-1441.

[32] Monahan F.J., German J.B., Kinsella J.E., Effect of $\mathrm{pH}$ and temperature on protein unfolding and thiol/disulfide interchange reactions during heat-induced gelation of whey proteins, J. Agric. Food Chem. 43 (1995) 46-52.

[33] Morales F.J., van Boekel M.A.J.S., A study on advanced Maillard reaction in heated casein/sugar solutions: colour formation, Int. Dairy J. 8 (1998) 907-915.

[34] Morgan F., Bouhallab S., Mollé D., Henry G., Maubois, J.-L., Léonil J., Lactosylation of $\beta$-lactoglobulin monitored by electrospray ionisation mass spectrometry, Int. Dairy J. 8 (1998) 95-98.

[35] Morgan F., Léonil J., Mollé D., Bouhallab S., Modification of bovine $\beta$-lactoglobulin by glycation in a powdered state or in aqueous solution: effect on association behavior and protein conformation, J. Agric. Food Chem. 47 (1999) 83-91.

[36] Odagiri S., Nickerson T.A., Micellar changes in skim milk treated with alkali or acid, J. Dairy Sci. 48 (1965) 1157-1160.

[37] Parker E.A., Donato L., Dalgleish D.G., Effects of added sodium caseinate on the formation of particles in heated milk, J. Agric. Food Chem. 53 (2005) 8265-8272. 
[38] Pouliot Y., Bouler M., Paquin P., Observations on the heat-induced salt balance changes in milk. I. Effect of heating time between 4 and $90{ }^{\circ} \mathrm{C}$, J. Dairy Res. 56 (1989) 185-192.

[39] Renan M., Mekmene O., Famelart M.-H., Guyomarc'h F., Arnoult-Delest V., Pâquet D., Brulé G., pH-dependent behaviour of soluble protein aggregates formed during heattreatment at $\mathrm{pH} 6.5$ and 7.2, J. Dairy Res. 73 (2006) 1-8.

[40] Rodriguez del Angel C., Dalgleish D.G., Structures and some properties of soluble protein complexes formed by heating of reconstituted skim milk powder, Food Res. Int. 39 (2006) 472-479.

[41] Schuck P., Piot M., Méjean S., Fauquant J., Brulé G., Maubois J.-L., Déshydratation des laits enrichis en caséine micellaire par microfiltration ; comparaison des propriétés des poudres obtenues avec celles d'une poudre de lait ultra-propre, Lait 74 (1994) 47-63.

[42] Singh H., Creamer L.K., Aggregation and dissociation of milk protein complexes in heated reconstituted concentrated skim milk, J. Food Sci. 56 (1991) 238-246.

[43] Smits P., van Brouwershaven J.H., Heatinduced association of $\beta$-lactoglobulin and casein micelles, J. Dairy Res. 47 (1980) 313-325.

[44] Vaia B., Smiddy M.A., Kelly A.L., Huppertz T., Solvent-mediated disruption of bovine casein micelles at alkaline $\mathrm{pH}$, J. Agric. Food Chem. 54 (2006) 8288-8293.

[45] Vasbinder A.J., De Kruif C.G., Casein-whey protein interactions in heated milk: the influence of pH, Int. Dairy J. 13 (2003) 669-677.

[46] Vasbinder A.J., Alting A.C., De Kruif C.G., Quantification of heat-induced casein-whey protein interactions in milk and its relation to gelation kinetics, Colloids Surf. B Biointerfaces, 31 (2003) 115-123.

[47] van Boekel M.A.J.S., Effect of heating on Maillard reactions in milk, Food Chem. 62 (1998) 403-414.

[48] van Vliet T., Roefs S.P.F.M., Zoon P., Walstra P., Rheological properties of casein gels, J. Dairy Res. 56 (1989) 529-534. 